\title{
Effect of Thymoquinone on Th1 and Th2 Balance in Rats Infected with Mycobacterium tuberculosis
}

\author{
Ery Olivianto ${ }^{1 *}$, Agustina Tri Endarti ${ }^{2}$ D, H. M. S. Chandra Kusuma ${ }^{3}$, Sanarto Santoso ${ }^{4}$, Kusworini Handono ${ }^{5}$ \\ ${ }^{1}$ Doctoral Program, Faculty of Medicine, Universitas Brawijaya, Malang, Indonesia; ${ }^{2}$ Department of Parasitology, Faculty of \\ Medicine, Universitas Brawijaya, Malang, Indonesia; ${ }^{3}$ Department of Child Health, Faculty of Medicine, Universitas Brawijaya, \\ Malang, Indonesia; ${ }^{4}$ Department of Microbiology, Faculty of Medicine, Universitas Brawijaya, Malang, Indonesia; ${ }^{5}$ Department \\ of Clinical pathology, Faculty of Medicine, Universitas Brawijaya, Malang, Indonesia
}

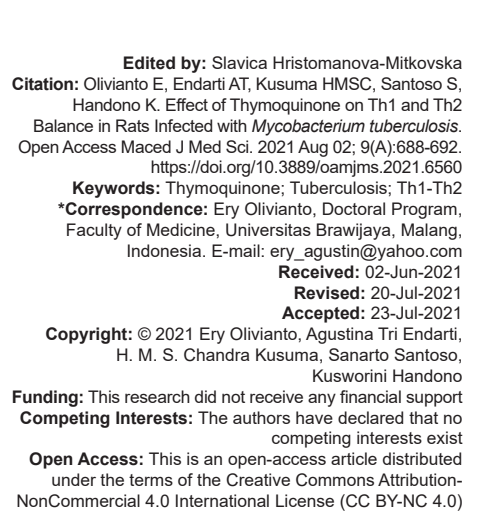

\begin{abstract}
BACKGROUND: Mycobacterium tuberculosis (TB) could alter the Th1 and Th2 balance by stimulating phagocyte IL-1 $\beta$ production, and subsequent Th2 differentiation. Thymoquinone (TQ) is an active compound of Nigella sativa which has a potential immunomodulatory effect in Th1 and Th2 balance.

AIM: We aim to evaluate the effect of TQ in restoring the Th1 and Th2 balance in MTB infection.

METHODS: Four groups of rats were infected with virulent MTB strain H37Rv. Different doses of TQ (25, 50, and 75 $\mathrm{mg} / \mathrm{kg} \mathrm{BW}$ ) were given to three groups, and one group was left without treatment. Additional one group was neither infected nor treated with TQ. We measure interleukin (IL)-1 $\beta$, IL-4, and interferon gamma (IFN- $-\mathrm{y}$ ) levels using ELISA 14 days after treatment.
\end{abstract}

RESULTS: We found there were increased IL-1 $\beta$, IL-4, and IFN- $\gamma$ levels after MTB infection, but we observed no significant effect of TQ treatment to Th1 and Th2 balance.

CONCLUSION: We conclude that TQ could not restore Th1 and Th2 balance in rats infected with MTB.

\section{Introduction}

Tuberculosis (TB) is still a major health problem worldwide. In 2018, it affects an estimated 10 million people and caused 1.2 million deaths among HIVnegative and additional 250,000 among HIV-infected patients. The global cumulative incidence reduction of only $6.3 \%$ does not meet expected $20 \%$ reduction of the 2020 milestone of end TB strategy [1].

Despite 69\% TB treatment coverage, the success rate was $85 \%$ for drug-sensitive TB (DS-TB) and $56 \%$ for multidrug-resistant (MDR-TB), suggesting there is still a gap needed to be addressed. Long period of oral anti-TB (OAT) treatment often causes patients' non-adherence. Furthermore, the emergence of drugresistant strain of Mycobacterium TB contributes to treatment failure to first-line OAT. The burden of MDR-TB with $18 \%$ of previously treated cases, compared to $3.4 \%$ of new cases, suggesting the failure to exterminate MTB in previous treatment is more likely to induce drugresistant strain. However, more than 50 years of new TB drugs research has resulted only a few agents used as second-line TB treatment. Alternative treatments such as agents expected to improve patients' immune response have been sought to help TB treatment more effective.

The study showed that during MTB infection, the microorganism could alter $\mathrm{T}$ cell polarization by increasing Th2 cytokines through stimulation of interleukin (IL)-1 $\beta$ production of dendritic cells, as well as inhibiting Th1 cytokines, which results in MTB escape from elimination within macrophage [2], [3]. Thus, immunomodulators that could increase Th1 cytokines and decrease Th2 cytokines are expected to make this bacteria elimination more effective.

Thymoquinone (TQ) is an active agent of Nigella sativa which is traditionally used for many diseases. It has been found that this active agent could inhibit Th2 inflammation in asthma models [4], [5], [6]. However, the effect of TQ on MTB infection has never been studied.

We aimed to study the effect of TQ on Th1 and Th2 cytokines in rats infected with MTB. 


\section{Methods}

\section{Design and ethics}

The animal experimental study was performed after ethical approval was obtained from the Research Ethics Commission of Brawijaya University (Approved ID: 924-KEP-UB). All rats used in this experiment were ethically killed by intramuscular injection of ketaminexylazine cocktail.

\section{Animals}

We used two months old female Rattus norvegicus rats for this study. The animals were maintained at the animal facility of the Institute of Tropical Disease Universitas Airlangga, Surabaya. The rats were placed within separated cages each of five rats. Food and water were supplied adequately.

\section{Inoculation}

MTB strain H37Rv was obtained from the Institute of Tropical Disease Universitas Airlangga, Surabaya. Aliquot contained $10^{5} \mathrm{cfu} / \mathrm{mL}$. Rats were anesthetized using intramuscular injection of ketaminexylazine 1:1.

\section{$T Q$}

TQ was purchased from Sigma Aldricht Co. The solution was constituted with dimethyl sulfoxide (DSMO) to make $10 \mathrm{mg} / \mathrm{mL}$ solution.

\section{Grouping}

Rats were divided into five groups, each consisted of five rats. Animals in all groups were infected by $0.2 \mathrm{~mL}$ of MTB strain H37Rv, except those in the negative control group.

After 3 weeks, groups 1-3 were given TQ 25, 50 , and $75 \mathrm{mg} / \mathrm{kg}$ body weight (BW) respectively. The positive (group 4) and negative (group 5) control groups were treated with DSMO only.

\section{Cytokines}

Cytokines IL-1 $\beta$, IL-4, and interferon gamma $(\mathrm{IFN}-\gamma)$ was measured using Rat IL-1 $\beta$ ELISA Kit, Rat IL-4 ELISA Kit, and Rat IFN- $\gamma$ ELISA Kit (Bioassay Technology Laboratory, Shanghai, China) in Laboratorium of Parasitology, Faculty of Medicine, Universitas Brawijaya.

\section{Results}

The level of IL-1 $\beta$ of positive control was significantly higher than negative control $(0.9 \pm 0.29 \mathrm{vs}$. $0.5 \pm 0.19 \mathrm{ng} / \mathrm{mL}, \mathrm{p}=0.007$ ). After treatment with $\mathrm{TQ}$, the level of IL-1 $\beta$ of treatment groups was not significantly different compared to that of the positive control group. However, groups treated with TQ tended to have a lower level of IL-1 $\beta$ compared to the positive control group, especially at dose $50 \mathrm{mg} / \mathrm{kg} \mathrm{BW}$ (Figure 1).

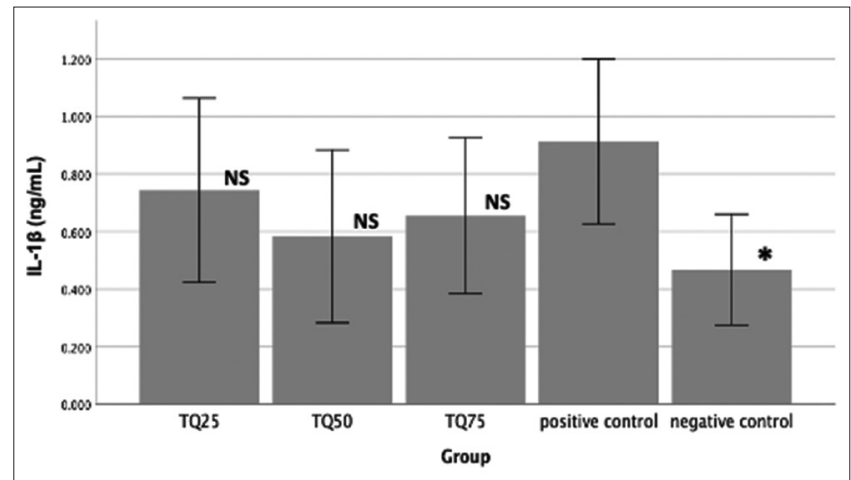

Figure 1: Level of interleukin-1 $\beta$ at 14 days after treatment with Thymoquinone at doses 25,50 and $75 \mathrm{mg} / \mathrm{kg}$ body weight. Statistical difference between positive control and other groups: ${ }^{*} p=0.007$; NS not significant

The level of IL-4 of positive control was significantly higher than negative control $(24.6 \pm$ 9.46 vs. $12.6 \pm 5.16 \mathrm{ng} / \mathrm{mL}, \mathrm{p}=0.022$ ). Although not significantly different, groups treated with $T Q$ at dose 50 and $75 \mathrm{mg} / \mathrm{kg}$ BW tended to have a lower level of IL-4 than that of the positive control group (Figure 2).

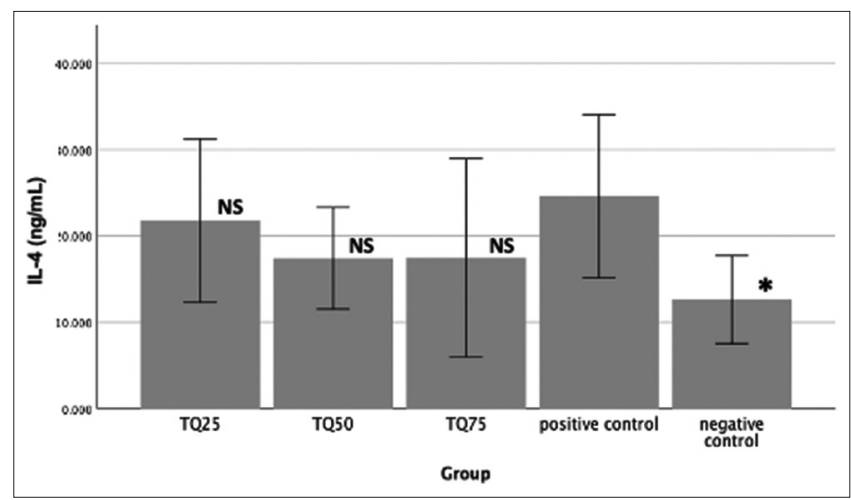

Figure 2: Level of interleukin-4 at 14 days after treatment with Thymoquinone at doses 25,50 and $75 \mathrm{mg} / \mathrm{kg}$ body weight. Statistical difference between positive control and other groups: ${ }^{*} p=0.022$; NS not significant

The level of IFN- $\gamma$ of positive control was significantly higher than the negative control $(24.4 \pm$ 4.16 vs. $16.1 \pm 2.50 \mathrm{ng} / \mathrm{mL}, \mathrm{p}=0.033$ ). Similar to that of IL-4, the level of IFN- $\gamma$ of groups treated with TQ at dose 50 and $75 \mathrm{mg} / \mathrm{kg} \mathrm{BW}$ tended to be lower than that of positive control group (Figure 3). 


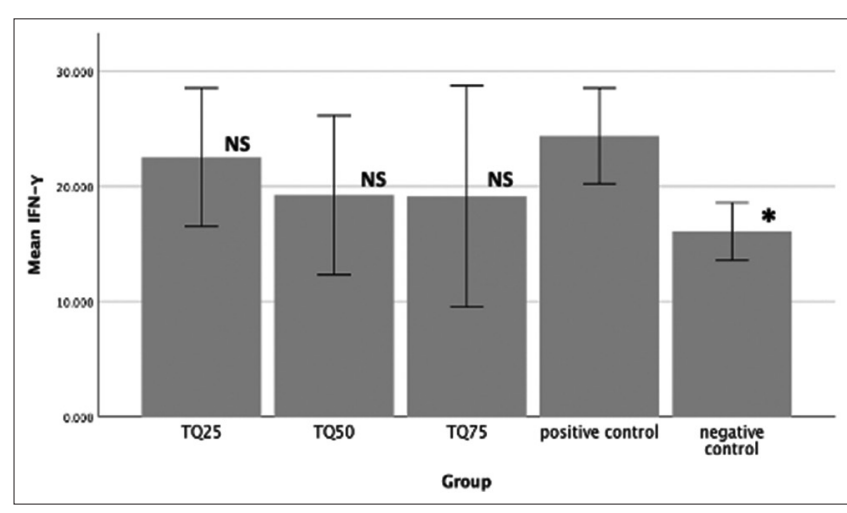

Figure 3: Level of interferon gamma at 14 days after treatment with Thymoquinone at doses 25, 50 and $75 \mathrm{mg} / \mathrm{kg}$ body weight. Statistical difference between positive control and other groups: ${ }^{*} p=0.033$; NS not significant

The ratio of IFN- $y^{\prime} \mid \mathrm{LL}-4$ was not significantly different between groups. However, the ratio tended to be similar between the group treated with $75 \mathrm{mg} / \mathrm{kg} \mathrm{BW}$ and negative control (Figure 4).

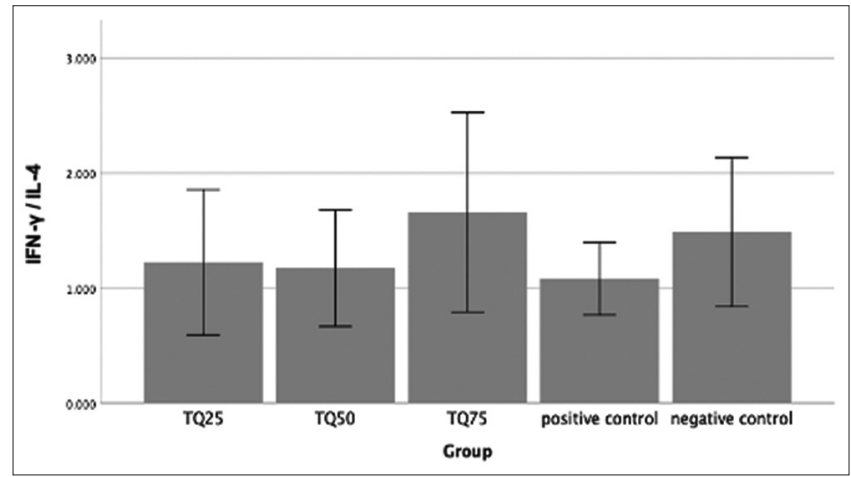

Figure 4: Ratio of interferon gamma to interleukin-4 at 14 days after treatment with Thymoquinone at doses 25, 50 and $75 \mathrm{mg} / \mathrm{kg}$ body weight. There was no statistical difference between group $(p=0.584)$

The level of IL-4 had strong correlation with the level of IL-1 $\beta(r=0.505 ; p<001)$ and moderate correlation with the level IFN- $\gamma(r=0.467 ; p=001)$ (Figure 5a and b).

\section{Discussion}

TQ is an active agent of $N$. sativa, which has traditionally been used for the treatment of various diseases. Wide studies have proven the ability of $\mathrm{TQ}$ to affect the immune system and this agent has been known to have antioxidative, anti-inflammatory, and immunomodulatory activities [7]. In addition to its antibacterial effect, TQ also has anti-tubercular activity in vitro [8], [9], [10]. An in vitro study had demonstrated TQ inhibitory effect on intracellular replication of MTB in mouse macrophage culture [11]. Furthermore, TQ has been believed to have an immunomodulatory effect on Th1 and Th2 balance [12]. So far, there is no studies have reported the effects of $T Q$ on the pathogenesis of MTB infection.

The balance of Th1-Th2 plays important role in macrophage polarization. Macrophages polarize into M1 in response to IFN- $\gamma$ released by infected macrophage as well as Th1 CD4 T-cell; and into M2 in response to Th2 cytokine such as IL-4 and IL-13 [13], [14], [15]. One study showed that MTB could alter T cell polarization by increasing Th2 cytokines through stimulation of IL-1 $\beta$ production of dendritic cells, as well as inhibiting Th1 cytokines, which results in MTB escape from elimination within macrophage [2]. Other study revealed the role of increased SOCS3 produced by macrophages infected with MTB [16].

$\mathrm{TQ}$ has been known as potential immunomodulator in several diseases. Studies had shown that TQ could modulate Th1 and Th2 balance in ovalbumin sensitized guinea pig [4], [5], [6]. The study by Xuan et al. in 2010 showed that TQ inhibits LPS-induced differentiation and maturation, as well as cytokine release of DC cultured from mice bone marrow [17]. Hence, there is a possibility that treatment with $T Q$ could decrease IL-4 levels, through inhibition of IL-1 $\beta$ by dendritic cells, and restore the balance toward Th1.

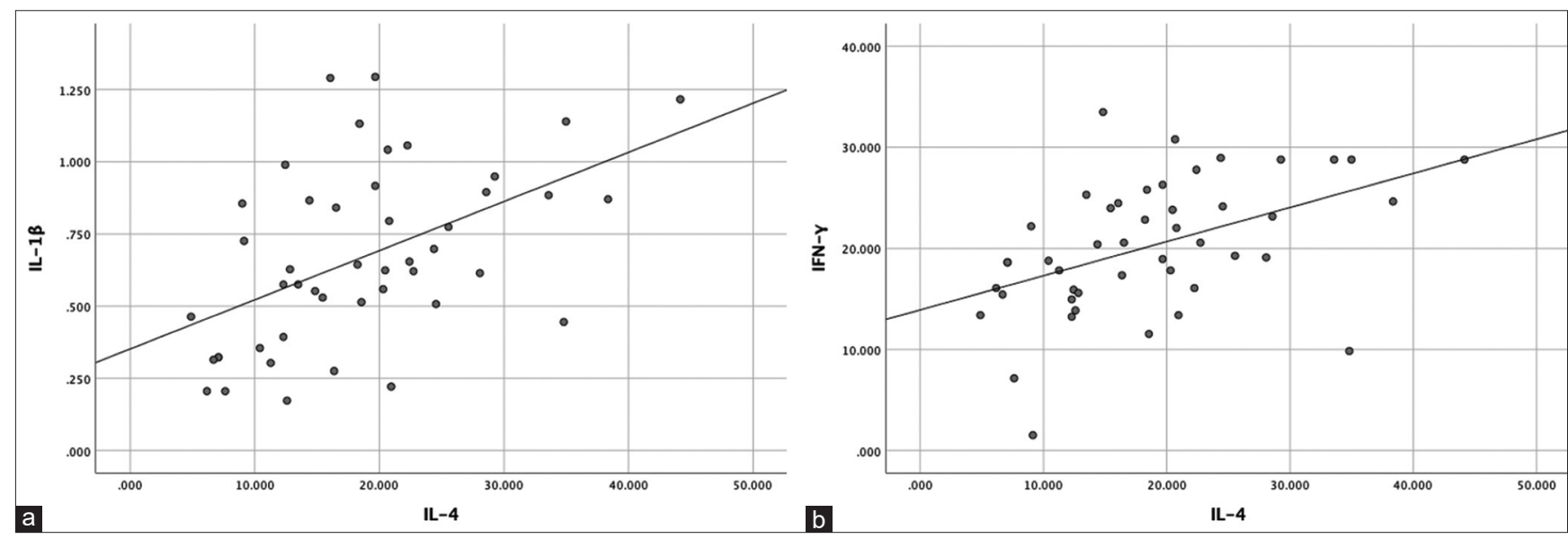

Figure 5: The correlation between interleukin (IL)-4 and IL-1 $\beta$ level. There was positive correlation $(r=0.505 ; p<001)$ between IL-4 level and IL-1 $\beta$ (a); the correlation between IL-4 level and interferon gamma (IFN- $\gamma$ ). There was positive correlation $(r=0.467 ; p=001)$ between IL-4 level and IFN- $\gamma(b)$ 
To the best of our knowledge, this study was the first to study the effect of TQ on TB disease. TQ was expected to restore Th1 and Th2 balance by inhibiting the production of IL-1 $\beta$ and IL-4, and increasing the ratio of IFN- $\gamma^{/} / \mathrm{L}-4$ in rats infected with MTB.

In this study, we found IL-1 $\beta$ level increase after infection of MTB. Upon virulent MTB strain H37Rv infection, copious amount of IL-1 $\beta$ is secreted by macrophage which is independent to the caspase-1 pathway and by dendritic cells, in which RD-1 antigen of MTB plays an important role [2], [18]. We found that the increase of IL-4 level was correlated with that of $\mathrm{IL}-1 \beta$ level. This suggests that the increase of IL-1 $\beta$, which might be produced by macrophage and dendritic cells after the infection of MTB, would affect the differentiation of CD4 toward Th2 cells. This finding is in concordant to the work of Dwivedi et al., which found that MTB infection could alter the balance toward Th2 differentiation dependent to IL-1 $\beta$ produced by dendritic cells [2].

We found in this study that the increase of IFN- $\gamma$ level following MTB infection. This cytokine is produced by activated macrophages upon phagocytosis of MTB. As inflammation progress and adaptive immune response is involved, IFN- $\gamma$ also secreted by Th1 $1 \mathrm{CD} 4^{+}$ cell and play important role in sustaining macrophage activation last longer [19], [20].

Although our study did not demonstrate a significant difference in IL-1 $\beta$, IL-4 and IFN- $\gamma$ levels after TQ treatment of MTB infected rats, there was a tendency of decreased IL-1 $\beta$ and IL-4 levels in groups treated with $\mathrm{TQ}$ at dose of $50 \mathrm{mg} / \mathrm{kg} \mathrm{BW}$. Likewise, an increase of IFN- $\gamma / \mathrm{LL}-4$ ratio tended to increase in groups treated with TQ at a dose of $75 \mathrm{mg} / \mathrm{kg} \mathrm{BW}$. However, we demonstrate that the IL-4 level was correlated to the IL-1 $\beta$ level.

Our finding was not in accordance with the results of studies which showed decreased IL-4 in sensitized allergic models treated with TQ [4], [6], [17]. The study by Miliani et al., 2018, showed increased production of IFN- $\gamma$ and IFN- $\gamma / \mathrm{IL}-4$ ratio in necrotic Jurkat $T$ cell line lysates-pulsed macrophage co-culture [21]. It seems that in infection models, particularly MTB infection, the alteration of Th1-Th2 balance is not as affected as in allergic disease by TQ treatment. Indeed, in this study, the IFN- $\gamma$ level was elevated in line with increase of IL-4 level. However, further research is required to explore the higher safe dose and longer duration of treatment, as well as its combination with standard anti TB drugs.

Our study had several limitations. We did not explore the serial observations of these cytokines before day-14 of TQ treatment, which may pose a dynamics concentration. Likewise, a longer duration of treatment may reveal different findings concerning these Th1 and Th2 cytokines. Second, we did not explore the effect of TQ treatment to MTB load in lung tissue, which may have been beneficial despite unchanged Th1-Th2 cytokine afer TQ treatment.

\section{Conclusion}

We demonstrate the increase of IL-1 $\beta$, IL-4, and IFN- $\gamma$ levels of rats infected with MTB. Treatment with TQ could not restore Th1 and Th2 balance. However, there is a chance to evaluate the potential of $\mathrm{TQ}$ as adjunctive treatment in TB.

\section{Acknowledgments}

The authors like to thank all laboratory staff in the Laboratorium of Parasitology, Faculty of Medicine, Universitas Brawijaya.

\section{Authors' Contributions}

E.O; A.T.E; S.S; H.M.S.C.: Study concept and design. E.O.: Acquisition of data. E.O; A.T.E.: Analysis and interpretation of data. E.O.: Drafting of the manuscript. A.T.E; S.S; H.M.S.C; K.H.: Critical revision of the manuscript for important intellectual content. E.O.: Statistical analysis.

\section{References}

1. Worl Health Organization. Global Tuberculosis Report 2019 Geneva: Worl Health Organization; 2019.

2. Dwivedi VP, Bhattacharya D, Chatterjee S, Prasad DV, Chattopadhyay D, van Kaer L, et al. Mycobacterium tuberculosis directs Thelper 2 cell differentiation by inducing interleukin- 1 beta production in dendritic cells. J Biol Chem. 2012;287(40):3365663. https://doi.org/10.1074/jbc.m112.375154

PMid:22810226

3. Pooran A, Davids M, Nel A, Shoko A, Blackburn J, Dheda K. IL-4 subverts mycobacterial containment in Mycobacterium tuberculosis-infected human macrophages. Eur Respir J. 2019;54(2):1802242. https://doi. org/10.1183/13993003.02242-2018

PMid:31097521

4. Boskabady MH, Keyhanmanesh R, Khameneh S, Doostdar $Y$, Khakzad MR. Potential immunomodulation effect of the extract of Nigella sativa on ovalbumin sensitized guinea pigs. J Zhejiang Univ Sci B. 2011;12(3):201-9. https://doi.org/10.1631/jzus. b1000163 


\section{PMid:21370505}

5. Keyhanmanesh R, Pejman L, Omrani H, Mirzamohammadi Z, Shahbazfar AA. The effect of single dose of thymoquinone, the main constituents of Nigella sativa, in guinea pig model of asthma. Bioimpacts. 2014;4(2):75-81. https://doi.org/10.9775/ kvfd.2015.14135

PMid:25035850

6. Keyhanmanesh $\mathrm{R}$, Boskabady $\mathrm{MH}$, Khamneh $\mathrm{S}$ Doostar Y. Effect of thymoquinone on the lung pathology and cytokine levels of ovalbumin-sensitized guinea pigs. Pharmacol Rep. 2010;62(5):910-6. https://doi.org/10.1016/ s1734-1140(10)70351-0

PMid:21098874

7. Darakhshan S, Pour AB, Colagar AH, Sisakhtnezha S Thymoquinone and its therapeutic potentials. Pharmacol Res. 2015;95-96:138-58. https://doi.org/10.1016/j.phrs.2015.03.011 PMid:25829334

8. Dera AA, Ahmad I, Rajagopalan P, Al-Shahrani M, Saif A, Alshahrani MY, et al. Synergistic efficacies of thymoquinone and standard antibiotics against multi-drug resistant isolates. Saudi Med J. 2021;42(2):196-204. https://doi.org/10.15537/ smj.2021.2.25706

PMid:33563739

9. Dey D, Ray R, Hazra B. Antitubercular and antibacterial activity of quinonoid natural products against multi-drug resistant clinical isolates. Phytother Res. 2014;28(7):1014-21. https://doi org/10.1002/ptr.5090

PMid:24318724

10. Randhawa MA. In vitro antituberculous activity of thymoquinone, an active principle of Nigella sativa. J Ayub Med Coll Abbottabad. 2011;23(2):78-81.

PMid:24800349

11. Mahmud HA, Seo H, Kim S, Islam MI, Nam KW, Cho HD, et al. Thymoquinone (TQ) inhibits the replication of intracellular Mycobacterium tuberculosis in macrophages and modulates nitric oxide production. BMC Complement Altern Med. 2017;17(1):279. https://doi.org/10.1186/s12906-017-1786-0 PMid:28545436

12. Gholamnezhad Z, Rafatpanah H, Sadeghnia HR, Boskabady $\mathrm{MH}$. Immunomodulatory and cytotoxic effects of Nigella sativa and thymoquinone on rat splenocytes. Food Chem Toxicol. 2015;86:72-80. https://doi.org/10.1016/j. fct.2015.08.028

PMid:26342766
13. Martinez J, Verbist K, Wang R, Green DR. The relationship between metabolism and the autophagy machinery during the innate immune response. Cell Metab. 2013;17(6):895-900. https://doi.org/10.1016/j.cmet.2013.05.012

PMid:23747248

14. O'Neill LA, Hardie DG. Metabolism of inflammation limited by AMPK and pseudo-starvation. Nature. 2013;493(7432):346-55. https://doi.org/10.1038/nature11862 PMid:23325217

15. Robb CT, Regan KH, Dorward DA, Rossi AG. Key mechanisms governing resolution of lung inflammation. Semin Immunopathol. 2016;38(4):425-48. https://doi.org/10.1007/s00281-016-0560-6 PMid:27116944

16. Ashenafi S, Aderaye G, Bekele A, Zewdie M, Aseffa G, Hoang AT, et al. Progression of clinical tuberculosis is associated with a Th2 immune response signature in combination with elevated levels of SOCS3. Clin Immunol. 2014;151(2):84-99. https://doi. org/10.1016/j.clim.2014.01.010 PMid:24584041

17. Xuan NT, Shumilina E, Qadri SM, Götz F, Lang F. Effect of thymoquinone on mouse dendritic cells. Cell Physiol Biochem. 2010;25(2-3):307-14. https://doi.org/10.1159/000276563 PMid:20110691

18. Krishnan N, Robertson BD, Thwaites G. Pathways of IL-1ß secretion by macrophages infected with clinical Mycobacterium tuberculosis strains. Tuberculosis (Edinb). 2013;93(5):538-47. https://doi.org/10.1016/j.tube.2013.05.002 PMid:23849220

19. Mosser DM, Edwards JP. Exploring the full spectrum of macrophage activation. Nat Rev Immunol. 2008;8(12):958-69. https://doi.org/10.1038/nri2448 PMid:19029990

20. Cavalcanti YV, Brelaz MC, Neves JK, Ferraz JC, Pereira VR Role of TNF-alpha, IFN-gamma, and IL-10 in the development of pulmonary tuberculosis. Pulm Med. 2012;2012:745483. https://doi.org/10.1155/2012/745483 PMid:23251798

21. Miliani M, Nouar M, Paris O, Lefranc G, Mennechet F, Aribi M. Thymoquinone potently enhances the activities of classically activated macrophages pulsed with necrotic jurkat cell lysates and the production of antitumor Th1-/M1-related cytokines. J Interferon Cytokine Res. 2018;38(12):539-51. https://doi. org/10.1089/jir.2018.0010

PMid:30422744 